\title{
1 SARS-CoV-2 detection in nasopharyngeal throat swabs by 2 metagenomics
}

4 Le Van Tan ${ }^{1}$, Nguyen Thi Thu Hong ${ }^{1}$, Nghiem My Ngoc ${ }^{2}$, Tran Tan Thanh ${ }^{1}$, Vo Thanh

$5 \quad$ Lam $^{2}$, Lam Anh Nguyet ${ }^{1}$, Le Nguyen Truc Nhu ${ }^{1}$, Nguyen Thi Han $\mathrm{Ny}^{1}$, Ngo Ngoc Quang

6 Minh $^{3}$, Dinh Nguyen Huy Man ${ }^{2}$, Vu Thi Ty Hang ${ }^{1}$, Phan Nguyen Quoc Khanh ${ }^{1}$, Tran Chanh

$7 \quad$ Xuan $^{4}$, Nguyen Thanh Phong ${ }^{2}$, Tran Nguyen Hoang Tu², Tran Tinh Hien ${ }^{1,5}$, Le Manh

8 Hung $^{2}$, Nguyen Thanh Truong ${ }^{2}$, Lam Minh Yen ${ }^{1}$, Nguyen Thanh Dung ${ }^{2}$, Guy Thwaites ${ }^{1,5}$,

9 Nguyen Van Vinh Chau ${ }^{2}$, for OUCRU COVID-19 research group*

$10 *$ Members of the Group are listed in the acknowledgements

11

12 Oxford University Clinical Research Unit, Ho Chi Minh City, Vietnam

$13{ }^{2}$ Hospital for Tropical Diseases, Ho Chi Minh City, Vietnam

$14{ }^{3}$ Children's Hospital 1, Ho Chi Minh City, Vietnam

$15{ }^{4} \mathrm{Cu}$ Chi Hospital, Ho Chi Minh City, Vietnam

$16{ }^{5}$ Centre for Tropical Medicine and Global Health, Nuffield Department of Medicine,

17 University of Oxford, Oxford, UK

18 Correspondence: Le Van Tan, email: tanlv@oucru.org

19 Abstract: 49

20 Main text: 1198

21 Running title: SARS-CoV-2 detection by metagenomics

22 Key words: COVID-19, SARS-CoV-2, coronaviruses, pandemic, Vietnam 
medRxiv preprint doi: https://doi.org/10.1101/2020.05.24.20110205; this version posted May 26, 2020. The copyright holder for this preprint (which was not certified by peer review) is the author/funder, who has granted medRxiv a license to display the preprint in perpetuity.

It is made available under a CC-BY 4.0 International license .

\section{ABSTRACT}

24 Metagenomics could detect SARS-CoV-2 in all eight nasopharyngeal/throat swabs with

25 high/low viral loads, and rhinovirus in a co-infected patient. The sequenced viruses

26 belonged to lineage B1. Because metagenomics could detect novel pathogen and co-

27 infection, and generate sequence data for epidemiological investigation, it is an attractive

28 approach for infectious-disease diagnosis. 
medRxiv preprint doi: https://doi.org/10.1101/2020.05.24.20110205; this version posted May 26, 2020. The copyright holder for this preprint (which was not certified by peer review) is the author/funder, who has granted medRxiv a license to display the preprint in perpetuity.

It is made available under a CC-BY 4.0 International license .

29 Metagenomics is a sensitive sequence-independence method for infectious disease diagnosis

30 and the discovery of novel pathogens [1]. The novel coronavirus namely severe acute

31 respiratory syndrome coronavirus 2 (SARS-CoV-2) is the cause of the ongoing coronavirus

32 disease 2019 (COVID-19) pandemic [2]. However, there have only been three studies

33 reporting the utility potential of metagenomics to detect SARS-CoV-2 directly from clinical

34 specimens, with a combined sample size of nine patients [3-5]. But none of these has been

35 conducted in resource-limited settings. In this area of the world, emerging infection however

36 is likely to emerge. Here we describe the application of metagenomics to detect SARS-CoV-

372 in RT-PCR positive nasopharyngeal throat swabs. In addition, using the obtained

38 sequence, we genetically characterize the viruses.

39 THE STUDY

40 Since the beginning of March, 2020 an observational study have been conducted at the

41 Hospital for Tropical Diseases (HTD) in Ho Chi Minh City, Vietnam and another one at one

42 of its two designated centres for receiving and treating COVI-19 patients from southern

43 Vietnam with a population of over 40 million (Figure 1). We enrolled patients with a

44 confirmed SARS-CoV-2 diagnosis admitted to the study settings within 48 hours. We

45 collected nasopharyngeal throat swabs (NTS), clinical and laboratory data, and travel and

46 contact history from each study participant. The collected NTS was stored at $4^{0} \mathrm{C}$ at the

47 study sites within four hours and was then transferred to the clinical laboratory of HTD for

48 analysis. SARS-CoV-2 detection was carried out using a WHO recommended real time RT-

49 PCR assays [6]. Assessment of co-infection with common respiratory viruses was carried

50 out using multiplex RT-PCR targeted at 15 different respiratory viruses [7]. The clinical

51 studies received approvals from the Institutional Review Board of the HTD and the Oxford 
medRxiv preprint doi: https://doi.org/10.1101/2020.05.24.20110205; this version posted May 26, 2020. The copyright holder for this preprint (which was not certified by peer review) is the author/funder, who has granted medRxiv a license to display the preprint in perpetuity.

It is made available under a CC-BY 4.0 International license .

52 Tropical Research Ethics Committee of the University of Oxford. Study participants gave

53 their written informed consent.

54 The selected samples were individually analyzed with the inclusion of a molecular grade

55 water sample serving as a non-template control (NTC). Metagenomics was carried out as

56 previously described [8]. DNA libraries of individual samples and NTC were then

57 multiplexed using double unique indexes (i.e. each sample was differentiated by double

58 barcodes) and sequenced on an Illumina MiSeq platform using a 300-cycle MiSeq reagent

59 kit V3 (Illumina). Detection of SARS-CoV-2 and co-infection viruses in the obtained

60 sequence data was carried out using a combination of publically availably metagenomics

61 pipelines namely IDseq (idseq.net) and DISCVR [9]. Reference based mapping approach

62 was applied to assemble SARS-CoV-2 genomes from the obtained sequences using

63 Geneious 11.0.3 (Biomatters, Auckland, New Zealand). SARS-CoV-2 lineage determination

64 and detections of nonsynonymous mutations were carried out using CoV-GLUE (http://cov-

65 glue.cvr.gla.ac.uk), a publically available tool for SARS-CoV-2 sequence analysis (Figure

$661)$.

67 As of March $19^{\text {th }}, 2020$, a total of 11 PCR confirmed SARS-CoV-2 patients were enrolled in

68 the clinical studies (Figure 1). As a pilot, we selected eight with a wide range of viral loads,

69 as reflected by real time Cycle threshold $(\mathrm{Ct})$ values, for metagenomics analysis (Figure

70 2A). Information about demographics and clinical status of the eight included patients are

71 presented in Table 1. All were adults and two were asymptomatic carriers identified through

72 contact tracing approach implemented in Vietnam [10]. Three were cases of locally acquired

73 infection and five were imported cases, and one was co-infected with rhihnovirus. 
medRxiv preprint doi: https://doi.org/10.1101/2020.05.24.20110205; this version posted May 26, 2020. The copyright holder for this preprint (which was not certified by peer review) is the author/funder, who has granted medRxiv a license to display the preprint in perpetuity.

It is made available under a CC-BY 4.0 International license .

74 Information about duration of stay and clinical and laboratory findings are presented in

75 Table 1.

76 Metagenomics generated a total of $2-4$ million reads per sample in $7 / 8$ included NTS. In the

77 remaining sample, $1 / 4$ million reads were obtained (Table 2). SARS-CoV-2 were detected in

78 sequence data obtained from all eight RT-PCR positive NTS samples by both IDseq and

79 DISCVR, but not in the NTS sample. One patient presenting with respiratory infection was

80 co-infected with rhinovirus, which was also detected by metagenomics.

81 Results of reference-based mapping showed three consensuses had genome coverage of

$82 \geq 70 \%$, while the remaining five had coverage of $<50 \%$ (Table 2 and Supplementary Figure

83 1). Analysis of the obtained consensuses showed all belong to lineage B1. A total of 11

84 nonsynonymous substitutions were detected in three of the eight obtained consensuses

85 (Supplementary Table 1).

86 CONCLUSIONS

87 The emergence of SARS-CoV-2 emphasizes the continuous unprecedented threat posed by

88 emerging infectious diseases, especially those caused by novel viruses. The diagnosis of

89 respiratory diseases is highly challenging because the responsible pathogens are diverse. In

90 addition, the emergence of novel pathogens further challenges routine diagnosis. Indeed,

91 SARS-CoV-2 initially went undetected by PCR panels targeted at common respiratory

92 viruses [2]. New diagnostic approach is therefore urgently needed to address the ongoing

93 challenge posed by emerging infections.

94 Here, we demonstrated that when coupled with publically available bioinformatics tools,

95 metagenomics could detect SARS-CoV-2 in RT-PCR positive NTS samples with a wide

96 range of viral loads. The data suggests that metagenomics is a sensitive assay for SARS- 
medRxiv preprint doi: https://doi.org/10.1101/2020.05.24.20110205; this version posted May 26, 2020. The copyright holder for this preprint

97 CoV-2 diagnosis and detection of co-infection as illustrated by the detection of rhinovirus,

98 in line with a recent report [4], important for clinical management. In addition to providing

99 diagnostic information, the obtained sequences also allows for genetic characterization, and

100 detection of genetic variations in the genomes of the pathogen under investigation. Indeed,

101 using the obtained sequences, we successfully identified that all the Vietnamese viruses

102 included for analysis belonged to lineage B1, which has been found worldwide [11]. In line

103 with a recent report [12], we identify several nonsynonymous substitutions in the obtained

104 genomes SARS-CoV-2. Further research is needed to ascribe the potential consequences

105 that SARS-CoV-2 evolution may have.

106 Currently, real time RT-PCR is used for screening of suspected cases of SARS-CoV-2

107 infection [6]. Compared with RT-PCR, metagenomics based on Illumina sequencing

108 technologies remains high cost and low throughput. However, these caveats could be

109 overcome by third generation sequencing technologies such as Oxford Nanopore [13],

110 which warrants further research.

111 The application of metagenomics for SARS-CoV-2 and respiratory diagnosis would be

112 highly relevant in the near future. This is because SARS-CoV-2 has spread globally, and

113 will likely soon become endemic worldwide. Indeed as of May $21^{\text {st }}, 2020$ nearly 5 million

114 cases have been reported globally. Notably, the vast majority of SARS-CoV-2 infections are

115 asymptomatic or mild, while COVID-19 patients present with signs/symptoms

116 undistinguished with respiratory diseases caused by other viruses [14, 15]. As such rapid

117 identification of the likely cause of hospitalized patients with respiratory infections is

118 essential for clinical management and outbreak response. Under this circumstance,

119 metagenomics is a preferable method because of its ability to detect both known and 
120 unknown pathogens presenting in the tested specimens without the need of pathogen

121 specific PCR primers $[1,13]$.

122 Our study has some limitations. Only a small number of patients were included for analysis,

123 owing to the nature of a pilot in itself. However during the study period, there were only 14

124 SARS-CoV-2 confirmed cases reported in our setting, Ho Chi Minh City, Vietnam. As a

125 consequence, we were not able to properly assess the sensitivity and specificity of

126 metagenomics for the diagnosis of COVID-19.

127 In summary, we show that metagenomics is a sensitive assay for sequence-independent

128 detection of SARS-CoV-2 NTS samples. The ability of metagenomics to detect co-infection

129 and novel pathogens, and generate sequence data for molecular epidemiological

130 investigation makes it an attractive approach for infectious disease diagnosis. 
medRxiv preprint doi: https://doi.org/10.1101/2020.05.24.20110205; this version posted May 26, 2020. The copyright holder for this preprint (which was not certified by peer review) is the author/funder, who has granted medRxiv a license to display the preprint in perpetuity.

It is made available under a CC-BY 4.0 International license .

131

132

133

134

135

136

137

138

139

140

141

142

143

144

145

146

147

148

149

150

151

152

153

154

155

156

157

158

159

160

161

162

163

164

165

166

167

\section{ACKNOWLEDGEMENTS}

This study was funded by the Wellcome Trust of Great Britain (106680/B/14/Z and 204904/Z/16/Z).

We are indebt to Ms Nguyen Thanh Ngoc, Ms Le Kim Thanh, and the OUCRU IT/CTU/Laboratory Management departments for their support.

We thank the patients for their participations in this study, and the doctors and nurses at HTD Cu Chi Hospital, who cared for the patients and provided the logistic support with the study.

\section{OUCRU COVID-19 Research Group}

Hospital for Tropical Diseases, Ho Chi Minh City, Vietnam: Nguyen Van Vinh Chau, Nguyen Thanh Dung, Le Manh Hung, Huynh Thi Loan, Nguyen Thanh Truong, Nguyen Thanh Phong, Dinh Nguyen Huy Man, Nguyen Van Hao, Duong Bich Thuy, Nghiem My Ngoc, Nguyen Phu Huong Lan, Pham Thi Ngoc Thoa, Tran Nguyen Phuong Thao, Tran Thi Lan Phuong, Le Thi Tam Uyen, Tran Thi Thanh Tam, Bui Thi Ton That, Huynh Kim Nhung, Ngo Tan Tai, Tran Nguyen Hoang Tu, Vo Trong Vuong, Dinh Thi Bich Ty, Le Thi Dung, Thai Lam Uyen, Nguyen Thi My Tien, Ho Thi Thu Thao, Nguyen Ngoc Thao, Huynh Ngoc Thien Vuong, Pham Ngoc Phuong Thao, Phan Minh Phuong

Oxford University Clinical Research Unit, Ho Chi Minh City, Vietnam: Dong Thi Hoai Tam, Evelyne Kestelyn, Donovan Joseph, Ronald Geskus, Guy Thwaites, H. Rogier van Doorn, Huynh Le Anh Huy, Huynh Ngan Ha, Huynh Xuan Yen, Jennifer Van Nuil, Jeremy Day, Joseph Donovan, Katrina Lawson, Lam Anh Nguyet, Lam Minh Yen, Le Nguyen Truc Nhu, Le Thanh Hoang Nhat, Le Van Tan, Sonia Lewycka Odette, Louise Thwaites, Maia Rabaa, Marc Choisy, Mary Chambers, Motiur Rahman, Ngo Thi Hoa, Nguyen Thanh Thuy Nhien, Nguyen Thi Han Ny, Nguyen Thi Kim Tuyen, Nguyen Thi Phuong Dung, Nguyen Thi Thu Hong, Nguyen Xuan Truong, Phan Nguyen Quoc Khanh, Phung Le Kim Yen, Sophie Yacoub, Thomas Kesteman, Nguyen Thuy Thuong Thuong, Tran Tan Thanh, Tran Tinh Hien, Vu Thi Ty Hang

\section{ABOUT THE AUTHOR}

Dr Le Van Tan is head of Emeging Infections at Oxford Univeristy Clinical Resarh Unit. His research interest includes novel diagnosis and emerging infections.

\section{REFERENCES}

1. Chiu, C.Y. and S.A. Miller, Clinical metagenomics. Nat Rev Genet, 2019. 20(6): p. 341-355.

2. Zhu, N., D. Zhang, W. Wang, X. Li, B. Yang, J. Song, X. Zhao, B. Huang, W. Shi, R. Lu, P. Niu, F. Zhan, X. Ma, D. Wang, W. Xu, G. Wu, G.F. Gao, W. Tan, I. China 
3. Chen, L., W. Liu, Q. Zhang, K. Xu, G. Ye, W. Wu, Z. Sun, F. Liu, K. Wu, B. Zhong, Y. Mei, W. Zhang, Y. Chen, Y. Li, M. Shi, K. Lan, and Y. Liu, RNA based mNGS approach identifies a novel human coronavirus from two individual pneumonia cases in 2019 Wuhan outbreak. Emerg Microbes Infect, 2020. 9(1): p. 313-319.

4. Peddu, V., R.C. Shean, H. Xie, L. Shrestha, G.A. Perchetti, S.S. Minot, P. Roychoudhury, M.L. Huang, A. Nalla, S.B. Reddy, Q. Phung, A. Reinhardt, K.R. Jerome, and A.L. Greninger, Metagenomic analysis reveals clinical SARS-CoV-2 infection and bacterial or viral superinfection and colonization. Clin Chem, 2020.

5. Ai, J.W., Y. Zhang, H.C. Zhang, T. Xu, and W.H. Zhang, Era of molecular diagnosis for pathogen identification of unexplained pneumonia, lessons to be learned. Emerg Microbes Infect, 2020. 9(1): p. 597-600.

6. Corman, V.M., O. Landt, M. Kaiser, R. Molenkamp, A. Meijer, D.K. Chu, T. Bleicker, S. Brunink, J. Schneider, M.L. Schmidt, D.G. Mulders, B.L. Haagmans, B. van der Veer, S. van den Brink, L. Wijsman, G. Goderski, J.L. Romette, J. Ellis, M. Zambon, M. Peiris, H. Goossens, C. Reusken, M.P. Koopmans, and C. Drosten, Detection of 2019 novel coronavirus (2019-nCoV) by real-time RT-PCR. Euro Surveill, 2020. 25(3).

7. Jansen, R.R., J. Schinkel, S. Koekkoek, D. Pajkrt, M. Beld, M.D. de Jong, and R. Molenkamp, Development and evaluation of a four-tube real time multiplex PCR assay covering fourteen respiratory viruses, and comparison to its corresponding single target counterparts. J Clin Virol, 2011. 51(3): p. 179-85.

8. Anh, N.T., N.T.T. Hong, L.N.T. Nhu, T.T. Thanh, C.Y. Lau, D. Limmathurotsakul, X. Deng, M. Rahman, N.V.V. Chau, H.R. van Doorn, G. Thwaites, E. Delwart, and L.V. Tan, Viruses in Vietnamese Patients Presenting with Community-Acquired Sepsis of Unknown Cause. J Clin Microbiol, 2019. 57(9).

9. Maabar, M., A.J. Davison, M. Vucak, F. Thorburn, P.R. Murcia, R. Gunson, M. Palmarini, and J. Hughes, DisCVR: Rapid viral diagnosis from high-throughput sequencing data. Virus Evol, 2019. 5(2): p. vez033.

10. Dinh, L., P. Dinh, P.D.M. Nguyen, D.H.N. Nguyen, and T. Hoang, Vietnam's response to COVID-19: Prompt and proactive actions. J Travel Med, 2020.

11. Rambaut, A., E.C. Holmes, V. Hill, Á. O’Toole, J.T. McCrone, C. Ruis, L. du Plessis, and O.G. Pybus, 2020.

12. van Dorp, L., M. Acmna, D. Richarch, P.L. Shaw, E.C. Fprd, L. Ormond, J.C. Owen, J. Pang, C.S.C. Tan, A.T.F. Boshier, T.A. Ortiz, and F. Balloux, Emergence of genomic diversity and recurrent mutations in SARS-CoV-2. Infection, Genetics and Evolution, 2020. in press.

13. Yang, L., G. Haidar, H. Zia, R. Nettles, S. Qin, X. Wang, F. Shah, S.F. Rapport, T. Charalampous, B. Methe, A. Fitch, A. Morris, B.J. McVerry, J. O'Grady, and G.D. Kitsios, Metagenomic identification of severe pneumonia pathogens in mechanicallyventilated patients: a feasibility and clinical validity study. Respir Res, 2019. 20(1): p. 265.

14. Goyal, P., J.J. Choi, L.C. Pinheiro, E.J. Schenck, R. Chen, A. Jabri, M.J. Satlin, T.R. Campion, Jr., M. Nahid, J.B. Ringel, K.L. Hoffman, M.N. Alshak, H.A. Li, G.T. Wehmeyer, M. Rajan, E. Reshetnyak, N. Hupert, E.M. Horn, F.J. Martinez, R.M. 

Engl J Med, 2020.

15. Grasselli, G., A. Zangrillo, A. Zanella, M. Antonelli, L. Cabrini, A. Castelli, D. Cereda, A. Coluccello, G. Foti, R. Fumagalli, G. Iotti, N. Latronico, L. Lorini, S. Merler, G. Natalini, A. Piatti, M.V. Ranieri, A.M. Scandroglio, E. Storti, M. Cecconi, A. Pesenti, and C.-L.I. Network, Baseline Characteristics and Outcomes of 1591 Patients Infected With SARS-CoV-2 Admitted to ICUs of the Lombardy Region, Italy. JAMA, 2020. 
medRxiv preprint doi: https://doi.org/10.1101/2020.05.24.20110205; this version posted May 26, 2020. The copyright holder for this preprint (which was not certified by peer review) is the author/funder, who has granted medRxiv a license to display the preprint in perpetuity.

It is made available under a CC-BY 4.0 International license .

Table 1: Demographics, clinical and real time RT-PCR data of the study participants

\begin{tabular}{|c|c|c|c|c|c|c|c|c|}
\hline & Patient 1 & Patient 2 & Patient 3 & Patient 4 & Patient 5 & Patient 6 & Patient 7 & Patient 8 \\
\hline Age range & 30 's & 40 's & 20 's & 30 's & 20 's & 20 's & 40 's & 10 's \\
\hline Gender & Male & Male & Male & Male & Female & Female & Female & Male \\
\hline Arriving in Vietnam from abroad (Yes/No) & Yes & Yes & No & No & No & Yes & Yes & Yes \\
\hline Locally acquired infection (Yes/No) & No & No & Yes & Yes & Yes & No & No & No \\
\hline Days from confirmed diagnosis to enrolment & 2 & 1 & 3 & 2 & 3 & 2 & 1 & 0 \\
\hline Days from admission to enrolment & 2 & 1 & 2 & 1 & 0 & 1 & 2 & 0 \\
\hline Duration of stay & 15 & NA & 17 & 18 & 15 & 12 & 13 & 17 \\
\hline Symptomatic (S)/asymptomatic (A) & $\mathrm{S}$ & $\mathrm{S}$ & S & A & S & A & $\mathrm{S}$ & $\mathrm{S}$ \\
\hline \multicolumn{9}{|l|}{ Laboratory results } \\
\hline White-cell count $(\times 103$ per $\mu 1)$ & 4.23 & 6.89 & 3.96 & NA & 6.85 & 4.83 & 3.46 & 8.27 \\
\hline Lymphocyte counts $(\times 103$ per $\mu \mathrm{l})$ & 0.8 & 0.54 & 1.08 & NA & 2.94 & 2.50 & 0.88 & 2.40 \\
\hline Hemoglobin $((\mathrm{g} / \mathrm{dl})$ & 13.6 & 14.6 & 16.8 & NA & 15.7 & 15.00 & 11.60 & 15.60 \\
\hline Hematocrit (\%) & 42.4 & 43.4 & 41.6 & NA & 37.4 & 35.78 & 28.48 & 38.09 \\
\hline Platelet count (per $\mu \mathrm{l})$ & 140 & 235 & 187 & NA & 414 & 321.00 & 178.00 & 330.00 \\
\hline Glucose $(\mathrm{mg} / \mathrm{dl})$ & 125.7 & 112 & 85 & NA & NA & NA & 76.80 & 98.50 \\
\hline Creatinine $(\mathrm{mg} / \mathrm{dl})$ & 0.96 & 1.28 & 1.2 & NA & NA & NA & 0.99 & 1.19 \\
\hline Aspartate aminotransferase (U/liter) & 24 & 17 & 22 & NA & NA & NA & 17.40 & 23.30 \\
\hline Alanine aminotransferase (U/liter) & 23 & 16 & 24 & NA & NA & NA & 17.40 & 25.30 \\
\hline \multicolumn{9}{|l|}{ Clinical signs/symptoms (Yes/No) } \\
\hline Fever & $\mathrm{Y}$ & $\mathrm{Y}$ & $\mathrm{Y}$ & $\mathrm{N}$ & $\mathrm{N}$ & $\mathrm{N}$ & $\mathrm{N}$ & $\mathrm{N}$ \\
\hline Cough & $\mathrm{N}$ & $\mathrm{Y}$ & $\mathrm{N}$ & $\mathrm{N}$ & $\mathrm{N}$ & $\mathrm{N}$ & $\mathrm{Y}$ & $\mathrm{N}$ \\
\hline Rhinorrhea & $\mathrm{N}$ & $\mathrm{N}$ & $\mathrm{Y}$ & $\mathrm{N}$ & $\mathrm{Y}$ & $\mathrm{N}$ & $\mathrm{N}$ & $\mathrm{Y}$ \\
\hline Fatigue & $\mathrm{N}$ & $\mathrm{Y}$ & $\mathrm{N}$ & $\mathrm{N}$ & $\mathrm{N}$ & $\mathrm{N}$ & $\mathrm{N}$ & $\mathrm{N}$ \\
\hline Diarrhea & $\mathrm{N}$ & $\mathrm{N}$ & $\mathrm{N}$ & $\mathrm{N}$ & $\mathrm{N}$ & $\mathrm{N}$ & $\mathrm{N}$ & $\mathrm{Y}$ \\
\hline Sore throat & $\mathrm{N}$ & $\mathrm{N}$ & $\mathrm{Y}$ & $\mathrm{N}$ & $\mathrm{N}$ & $\mathrm{N}$ & $\mathrm{Y}$ & $\mathrm{N}$ \\
\hline Muscle pain & $\mathrm{N}$ & $\mathrm{Y}$ & $\mathrm{N}$ & $\mathrm{N}$ & $\mathrm{N}$ & $\mathrm{N}$ & $\mathrm{Y}$ & $\mathrm{N}$ \\
\hline Headache & $\mathrm{N}$ & $\mathrm{Y}$ & $\mathrm{N}$ & $\mathrm{N}$ & $\mathrm{N}$ & $\mathrm{N}$ & $\mathrm{N}$ & $\mathrm{N}$ \\
\hline Abdominal pain & $\mathrm{N}$ & $\mathrm{N}$ & $\mathrm{N}$ & $\mathrm{N}$ & $\mathrm{N}$ & $\mathrm{N}$ & $\mathrm{N}$ & $\mathrm{N}$ \\
\hline Lost sense of smell & $\mathrm{N}$ & $\mathrm{N}$ & $\mathrm{N}$ & $\mathrm{N}$ & $\mathrm{Y}$ & $\mathrm{N}$ & $\mathrm{N}$ & $\mathrm{N}$ \\
\hline
\end{tabular}


medRxiv preprint doi: https://doi.org/10.1101/2020.05.24.20110205; this version posted May 26, 2020. The copyright holder for this preprint (which was not certified by peer review) is the author/funder, who has granted medRxiv a license to display the preprint in perpetuity.

It is made available under a CC-BY 4.0 International license.

Table 2: Results of mNGS and lineage assignment SARS-CoV-2 sequences

\begin{tabular}{|c|c|c|c|c|c|}
\hline $\begin{array}{c}\text { Patient } \\
\text { number }\end{array}$ & Ct values & $\begin{array}{c}\text { Total single } \\
\text { reads }\end{array}$ & $\begin{array}{c}\text { No of SARS-CoV-2 } \\
\text { reads }\end{array}$ & $\begin{array}{c}\text { \% SARS-CoV-2 } \\
\text { genome coverage }\end{array}$ & $\begin{array}{c}\text { SARS-CoV-2 } \\
\text { lineage }\end{array}$ \\
\hline 1 & 26.52 & $3,182,758$ & 84 & 16 & $\mathrm{~B} 1$ \\
\hline 2 & 21.47 & $4,218,464$ & 6930 & 70 & $\mathrm{~B} 1$ \\
\hline 3 & 27.06 & $2,735,464$ & 573 & 36 & $\mathrm{~B} 1$ \\
\hline 4 & 32.09 & $1,902,512$ & 68 & 12 & $\mathrm{~B} 1$ \\
\hline 5 & 24.81 & 245,818 & 14 & 3 & $\mathrm{~B} 1$ \\
\hline 6 & 25.68 & $3,524,972$ & 995 & 48 & $\mathrm{~B} 1$ \\
\hline 7 & 24.56 & $2,440,326$ & 16564 & 87 & $\mathrm{~B} 1$ \\
\hline 8 & 24.13 & $3,253,308$ & 9095 & 80 & $\mathrm{~B} 1$ \\
\hline
\end{tabular}




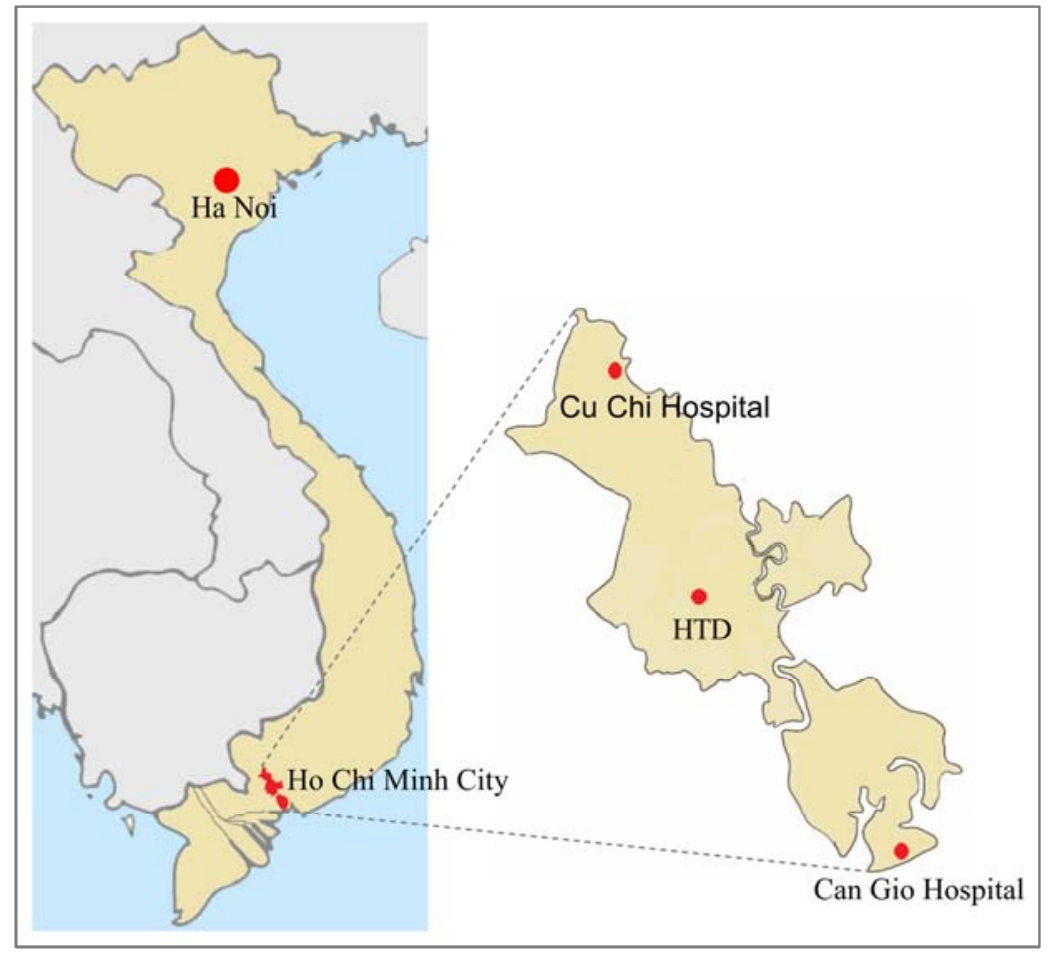

Figure 1: Flowchart showing the study settings and the clinical studies. (A) Map showing the location of the Hospital for Tropical Diseases (HTD) main campus and its designated COVID-19 centres in $\mathrm{Cu}$ Chi where the clinical study was conducted, and Can Gio, (B) Flowchart illustrating the patient enrolment, mNGS analysis and post run analysis of the obtained sequences

\section{Note to Figure 1:}

Maps were obtained from https://mapchart.net/.

\section{Clinical study 1}

Setting: Hospital for Tropical Diseases Starting date March $1^{\text {st }}, 2020$
Clinical study 2

Setting: $\mathrm{Cu}$ Chi Hospital Starting date March $10^{\text {th }}, 2020$

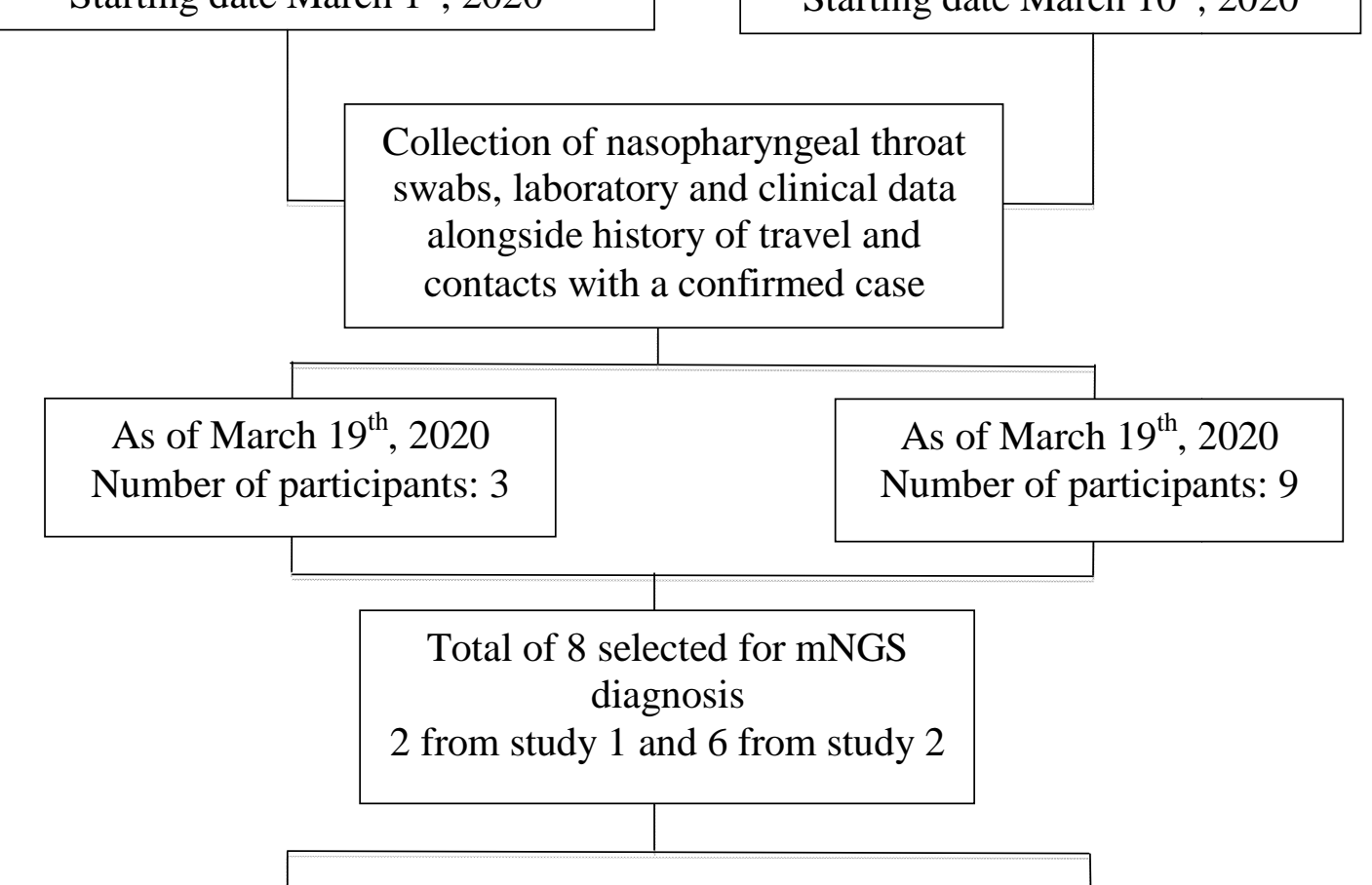

Further testing for co-infection using multiplex PCRs targeted at 15 respiratory viruses

\section{Metagenomics: Nuclease treatment, NA isolation, random PCR and Illumina MiSeq sequencing of individual samples}

\section{CoV-GLUE: SARS-CoV-2 \\ lineage assignment and nucleotide variation detection}

Geneious: whole genome sequence assembly
IDseq/DISCVR: viral species detection 

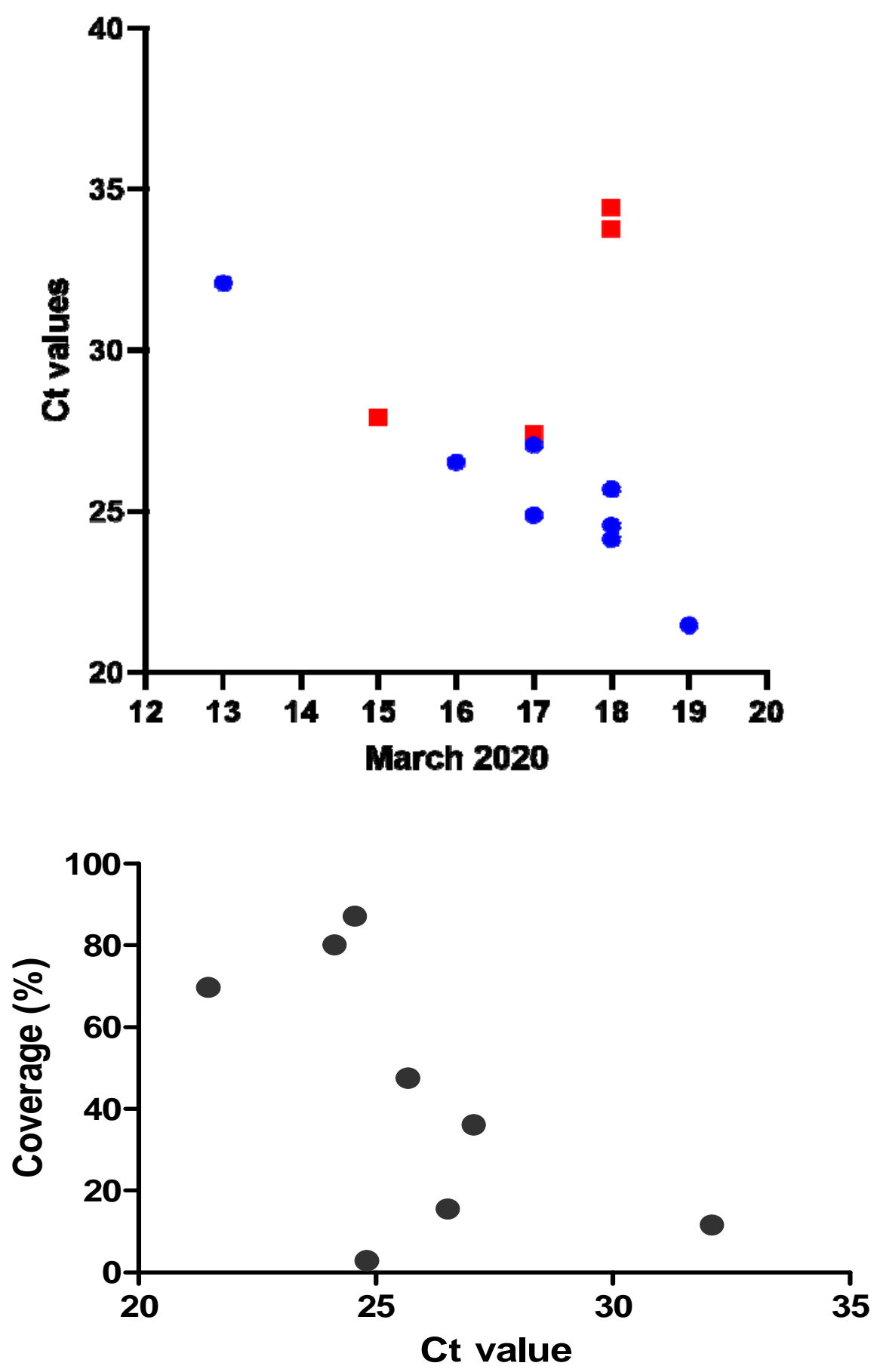

Figure 2: Distribution of $\mathrm{Ct}$ values of nasopharyngeal throat swabs of the study participant (A), and the association between $\mathrm{Ct}$ values and genome coverage of SARS-CoV-2 generated by mNGS (B)

Note to Figure 2A: Blue dot represent for samples selected for mNGS while red squares represent for samples not selected for mNGS. Numbers on the $\mathrm{X}$ axis represent for calendar days of March 2020 
Supplementary Table 1: list of non synonymous substitution detected in eight consensuses of the present study

\begin{tabular}{|c|c|c|c|c|}
\hline & $\begin{array}{l}\text { Nucleotide } \\
\text { variation* }\end{array}$ & Coding Region & $\begin{array}{l}\text { Amino acid } \\
\text { change }\end{array}$ & $\begin{array}{l}\text { Detected in } \\
\text { GenBank }\end{array}$ \\
\hline Patient 6 & $17104 \mathrm{C}>\mathrm{T}$ & nsp13 & H290Y & Yes \\
\hline \multirow{5}{*}{ Patient 7} & $14407 \mathrm{C}>\mathrm{T}$ & nsp12 & P323L & Yes \\
\hline & $23402 \mathrm{G}>\mathrm{A}$ & $\mathrm{S}$ & D614G & Yes \\
\hline & $28881 \mathrm{G}>\mathrm{A}$ & $\mathrm{N}$ & R203K & Yes \\
\hline & $28882 G>A$ & $\mathrm{~N}$ & R203K & Yes \\
\hline & $28883 \mathrm{G}>\mathrm{C}$ & $\mathrm{N}$ & G204R & Yes \\
\hline \multirow{5}{*}{ Patient 8} & $14407 \mathrm{C}>\mathrm{T}$ & nsp12 & P323L & Yes \\
\hline & $23402 \mathrm{G}>\mathrm{A}$ & $\mathrm{S}$ & D614G & Yes \\
\hline & $28881 G>A$ & $\mathrm{~N}$ & R203K & Yes \\
\hline & $28882 G>A$ & $\mathrm{~N}$ & R203K & Yes \\
\hline & $28883 \mathrm{G}>\mathrm{C}$ & $\mathrm{N}$ & G204R & Yes \\
\hline
\end{tabular}

Note to supplementary Figure 1: *compared with reference strain (GenBank accession number NC_045512.2) 
Reference NCBI Entry MN994468.1 - Wuhan s...

Reference Length 29883

\section{Aligned Contigs}

Aligned Loose Reads
Reference Accession

Contigs (16)

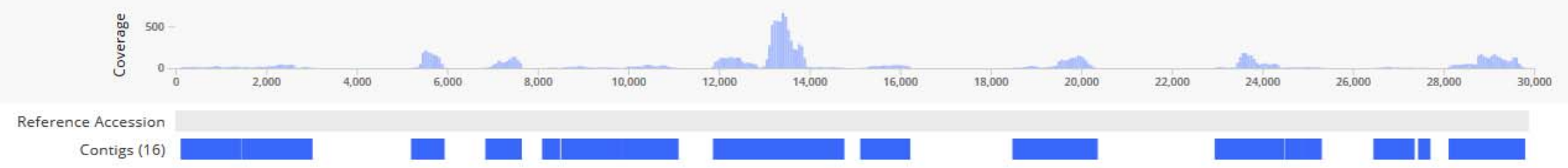

\section{Coverage Depth}

Coverage Breadth
$35.2 x$

$62.2 \%$
Max Alignment Length 2904

Avg. Mismatched $\%$

Supplementary Figure 1: A screen shot showing evidence of SARS-CoV-2 detection in metagenomics data using IDseq pipeline

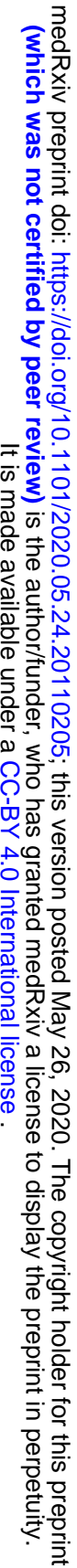

